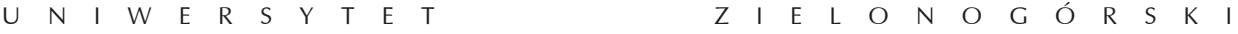

Przegląd Narodowościowy - Review of Nationalities

Jews $\mathrm{nr} 6 / 2016$

DOI: $10.1515 / p n-2016-0007$

ISSN 2084-848X (print) ISSN 2543-9391 (on-line)

Bartłomiej Secler*

\title{
Twenty years of diplomatic relations between Vatican City state and Israel
}

KEYWORDS: Israel, Vatican City State, relations, Basic Agreement

sŁowa kluczowe: Izrael, Państwo Watykańskie, relacje, Porozumienie Podstawowe

In 2014, it was twenty years since the signing of the Basic Agreement ${ }^{1}$ between the Vatican City State and the State of Israel. The document of historic significance was an important step to establish full diplomatic relations. The event had been preceded by long years of complex bilateral political contacts. Moreover, it is worth remembering about two thousand years of religious intricate relationships. There is no doubt that the Catholic-Jewish relations for decades far from ideal influenced the realm of political agreement.

The primary objective of this article is the analysis of the agreement concluded in the nineties of the last century and attempt to assess the relations between the Vatican City State and Israel by showing the dynamics of this relationship and the problems and disputes from the perspective of the last twenty years. In the first part of the text (excluding the introduction), I would like, however, to look in a synthetic way at the contacts of the Holy See and Israel covering the period before the conclusion of the Basic Agreement. In the next two sections, I analyze the provisions of the agreement and pay attention to some problems of the difficult diplomatic relations. Not without significance is also the assessment of the current state of relations between the Holy See and Israel, with particular emphasis on the Agreement signed by Santa Sede and the Palestinians in 2015. In the final part of the text, I will present conclusions.

* Assistant Professor, Faculty of Political Science and Journalism, Adam Mickiewicz University in Poznań. Mail: bartlomiej.secler@amu.edu.pl.

1 Fundamental Agreement between the Holy See and the State of Israel, 30 December 1993. Israel Ministry of Foreign Affairs,

http://www.mfa.gov.il/mfa/foreignpolicy/mfadocuments/yearbook9/pages/151\%20fundamental\%20agreement\%20between\%20the\%20holy\%20see\%20and.aspx, 24.05.2015. 
Taking into account the above outlined research problem, in this article, I am going to answer the questions referring to:

- The specificity of political and religious relations linking the Holy See and Israel;

- The importance of the Basic Agreement signed in 1993;

- Fundamental problems and challenges in diplomatic relations of abovementioned entities;

- The main axis of disputes and conflicts between the Holy See and Israel;

- Popes' attitude to the Jewish question and their contribution to the development of diplomatic relations with Israel (John Paul II, Benedict XVI, Francis).

In accordance with canon 361 of the Code of Canon Law of $1983^{2}$ „In this Code, the term Apostolic See or Holy See refers not only to the Roman Pontiff but also to the Secretariat of State, the Council for the Public Affairs of the Church, and other institutes of the Roman Curia, unless it is otherwise apparent from the nature of the matter or the context of the words". It is therefore considered that the Holy See is the Pope and the Roman Curia, which helps him to manage the universal Church. Santa Sede is a subject of international law. Tomasz Olejarz argues that it is undisputed that "in the pragmatics of the international operation of the Holy See there are certain elements of abnormalities, structurally different than in the case of »classical« government entities and other participants in the international environment" ${ }^{\text {. }}$ Undoubtedly, the Holy See has all the attributes of an international legal subjectivity, which have been shaped by centuries of tradition.

Specific importance of the Holy See is expressed through its specific relationship with the State of Vatican City. This combination stemming from Lateran Pacts of 1929 was aimed at strengthening Santa Sede in international relations, as well as the formation of its subjectivity in the contemporary dimension. The Holy See has, according to Józef Krukowski, the subjectivity and is a representative of the Catholic Church in the international arena ${ }^{4}$. „In practice, the Holy See as a sovereign entity decides independently in what capacity it concludes international agreements on the matter"5, explains the researcher.

2 Code of Canon Law of 25 January 1983.

3 See more: T. Olejarz, Podmiotowość Stolicy Apostolskiej w stosunkach międzynarodowych, „Annales Universitatis Mariae Curie-Skłodowska” (sectio K) No 1, 2009, p. 68.

4 J. Krukowski, Konkordaty z państwami Europy Środkowej i Wschodniej zawarte na przełomie XX i XXI wieku, „Teka Komisji Prawniczej O.L. PAN” No 3, 2010, p. 96.

5 Ibidem, p. 96. 
The attributes of the Holy See also confirm its international legal subjectivity, i.e. the right of legation, the right to conclude international agreements, the right to be a member of an international organization. In the case of the right of legation, the Holy See can send and receive diplomatic representatives. However, in case of ius contrahendi, the Holy See concludes concordats and may be signatory to bilateral and multilateral international agreements. The Secretariat of State and the apostolic nunciatures carry out diplomacy of Santa Sede. It is worth noting that the bilateral diplomatic contacts are important for the Holy See because of the possibility of regulating legal and financial situation of the local Churches. It should also be noted that diplomacy is also conducted directly by the Pope. It may have the nature of audience that means receiving heads of state, heads of government and foreign ministers, as well as the active dimension which manifests even in the apostolic journeys.

\section{Relations the Holy See - Israel in historical perspective}

Robert Klarecki in his book on politics of the Holy See toward China rightly points out that the history of relations between Santa Sede and the countries "is full of friction and embitterment"6. This thesis is fully in line with the Holy See's relations with Israel. Already in the nineteenth century, the Holy Capital closely watched, while expressing its concern about the situation and controlling the holy places in Palestine and especially in Jerusalem, which, once considered the „center of the world"7, soon became the scene of fighting of representatives of the three major religions: Christianity, Judaism, and Islam. Many Popes focused their attention on this place. In 1887, considered the first modern Pope seeking to dialogue with the modern world, Pope Leo XIII issued a motu proprio ${ }^{8}$ entitled Domini et Salvatoris ${ }^{9}$. The papal document called for a creation of a fund whose purpose would be to keep the Holy Land, in particular Jerusalem. After more than a century, in October 1999, on a symposium on the 50th anniversary of the Pontifical Mission for Palestine at the New York headquarters of the United Nations, Archbishop Jean-Louis Tauran said about the importance of the motu proprio ${ }^{10}$. According to the hierarch the document of Leo XIII, together with the statements of the later popes Benedict XV and Pius XI on the holy places, he created

6 R. Klarecki, Polityka Stolicy Apostolskiej wobec Chin. Przeszłość, teraźniejszość i przyszłość, Toruń 2014, p. 33.

7 S.S. Montefiore, Jerusalem. Biography, New York 2011, p. 11.

8 Motu Proprio (Latin from my own Initiative) is a letter in the rank of a papal decree resulting from the initiative of the Pope.

9 From Latin: Lord and Saviour.

10 Jean-Louis Tauran, the French priest and diplomat, since 2003 Cardinal of the Catholic Church. In the years 1975-1983 a secretary of nunciatures sequentially in the Dominican Republic and Lebanon. In 1990 he was appointed by Pope John Paul II's the secretary for relations with 
a bridge between two different, existing in the region, political situations ${ }^{11}$. Moreover, Archbishop Tauran pointed out that a careful analysis of church documents allows distinguishing three phases of activity of the Holy See in the Holy Land in the nineteenth and twentieth century, although - of course - the region has aroused the interest of the popes and the Church since the Middle Ages. The first period attributable to the period from the end of the nineteenth century until 1947, was characterized by the concern expressed by successive popes to Catholics around the world not to forget about the need for material support holy places. Leo XIII told the clergy to organize „the collect for the holy places"12. Benedict XV also spoke on the holy places and the rights that Christianity had towards them. Moreover, with concern he drew attention to the plight of Palestine demanding, among others, „respect for the inalienable rights which all Christians have there"13. Pius XI spoke in a similar vein, and his successor, already in the second period indicated by the Archbishop Tauran (1947-1964), devoted much attention to the Holy Land, which was reflected in specific ideas and actions. Pius XII, as noted by Archbishop Tauran, „introduced the debate on the Middle East, a new element of pastoral and political nature; ensuring the impartiality of the Holy See and condemning violence "from either side it would not come«, he also emphasized strongly that such impartiality in no way implies "indifference " 14 . Repeatedly, in encyclicals and speeches, he articulated complicated problem of holy places, calling for reconciliation, peace and justice. After the death of Pius XII on 9 October 1958, residing in New York, Foreign Minister of Israel, Golda Meir wrote in a telegram to the Vatican: „We join with all of humanity in mourning over the death of His Holiness Pope Pius XII. During the times tormented by wars and conflicts he could remain faithful to the sublime ideals of peace and love. When, during the ten years of Nazi terror, our nation underwent the most terrible martyrdom, the Pope's voice was heard for the victims. Life at that time enriched the word, which, rising above the tumult of daily conflict, proclaimed the highest moral truths. We cry over the departure of a truly great servant of peace" 15 . In a similar vein, many other representatives of the Jewish community commented then. Four decades later, authoritative representatives of the Jewish people would adopt quite a different attitude toward Pius XII, publicly demanding the aban-

states at the Vatican Secretariat of State. In 2007, Benedict XVI appointed him the President of the Pontifical Council for Interreligious Dialogue.

11 J.L. Tauran, Stolica Apostolska i Ziemia Święta: sprawiedliwość i miłosierdzie, http://www. opoka.org.pl/biblioteka/T/TH/THW/sprawiedliwosc_milosierdzie.html, 6.06.2015.

12 Ibidem.

13 Cited from: ibidem.

14 Ibidem.

15 A. Tornielli, Pius XII. Papież, który ratowat Żydów, Kraków 2015, p. 32. 
donment of the Vatican's beatification process ${ }^{16}$. Undoubtedly, during the Pope's life, the belief dominated that he was a defender of the Jews. The problem of the silence of Pius XII on the Holocaust became loud when the play The Deputy, a Christian tragedy by Rolf Hochhuth was staged in Kurfürstendamm Theater in Berlin in February 1963. The beatification process started in November 1965. Many years later, in May 2007, cardinals and bishops of the Congregation for the Causes of Saints voted for the beatification of the Pope. However, after a few months, in December 2007, the decision of Benedict XVI stopped the process of recognition Pius XII the blessed. The basis for this decision was the fear of the consequences that the beatification would bring to VaticanIsrael relations and dialogue with Judaism. In 2009, the present Senior Pope authorized the above-mentioned congregation to issue a decree about the heroic virtues of Pius XII, who has had the right to the title of Venerable Servant of God since then.

The third phase of activity of the Holy See in the Holy Land has been continuing since 1964. It is worth emphasizing the voice of Vaticanum Secundum (The Second Vatican Council), which drew attention to the three dimensions of Jerusalem - earthly, human and spiritual. The latter has become a leitmotif of papal statements in the subsequent decades. The Holy See continues to insist on appropriate international regulations, which would help to end military and political conflicts in the Holy Land. The region also gained special significance for the papal diplomacy during the pontificate of John Paul II. Suffice it to mention the efforts related to the peaceful settlement of the question of the Middle East in terms of confirming the existence of the State of Israel and its right to ensure their own security, but also the right of the Palestinians to their own land ${ }^{17}$. The predecessor of the Polish Pope (not including here John Paul I), Paul VI, as rightly notes Gregory Ignatowski, was not well received by the Jewish community. The cause of the critical attitude towards the Pope was his attitude towards the State of Israel during a pilgrimage to the Holy Land on 4-6 January 1964. „Paul VI even once, even during official meetings with Israeli President Zalman Shazar, did not mention the name of the Jewish state, and described Israelis as »the sons of the covenant $«$. During his short pilgrimage he lacked time for the visit in the Israel's official memorial to the victims of the Holocaust Yad Vashem"18, observes G. Ignatowski.

The consequence of the partition of Palestine in 1947 by the United Nations into the Jewish and Arab states was the proclamation of independence by Israel a year later: „(...) by virtue of our natural and historic right and on the basis of the resolution of

16 Ibidem, p. 37. On the subject of relations between the Holy See and Germany in the twenties and thirties of the twentieth century, see: G. Besier, Stolica Apostolska i Niemcy Hitlera, Warszawa 2010.

17 J.L. Tauran, Stolica Apostolska.

18 G. Ignatowski, Stolica Apostolska wobec Państwa Izrael w okresie wojny sześciodniowej, „Śląskie Studia Historyczno-Teologiczne" vol. 42, book 2, 2009, pp. 144-145. 
the united nations general assembly, hereby we declare the establishment of a Jewish state in Eretz-Israel, to be known as the state of Israel"19. As the first the United States and the Soviet Union recognized the new state on the political map of the world. The above-mentioned interest of the Holy See to the Holy Land undoubtedly had an impact on political relations with Israel. Diplomatic relations established in 1993 were preceded by several decades of difficult relations and diplomatic actions. The first „grating" was the objection of Vatican against Israel's membership in the United Nations. In the background of these events there was, among others, the problem of Israel's sovereignty over Jerusalem. In published in 1949 encyclical of Pius XII Redemptoris Nostri Cruciatus, the Pope expressed concern about the future and freedom of access to the holy places and their international status. Moreover, under the new circumstances, after the proclamation of independence, the Holy See sought to protect Christian and Catholic values in Jerusalem. Largely on this very background, a variety of disputes occurred in subsequent decades, the consequence of which there was the absence of a diplomatic agreement.

Analyzing the political relations between the Holy See and Israel, we can not forget the religious context, maintained for centuries the time full of animosity, blame and recriminations. However, as emphasized by Leo Trepp, a change of thinking in Christian circles influenced on the positive attitude of the world towards the Jews, and the Catholic Church proposed the idea of improving relations between Judaism and Christianity ${ }^{20}$. „It is the Church because of its »theological anti-Judaism «, of which result was the deprivation of rights and persecution of the Jews, which created in the past the foundations of the anti-Semitism grown hundreds of years later. And the modern anti-Semitism eventually led to the extermination of six million Jews", wrote died in 2010 Rabbi Trepp. In my opinion, one of the most important, in this context, events in October 1965 was the announcement of the Declaration Nostra aetate ${ }^{21}$, the work of Vatican II, essentially changing the relationship of the Church with the Jews, although it should be added that the document concerned the relation of the Church to nonChristian religions in general. In relation to Judaism, it stated inter alia that God's covenant with Israel has never been broken, and the Jews are responsible for Jesus' death. It is also necessary to condemn the persecution of the Jewish population, and together with the Christians they are invited to dialogue and understanding. Despite the im-

19 The Declaration Of The Establishment Of The State Of Israel, 14 May 1948, http://www.mfa. gov.il/mfa/foreignpolicy/peace/guide/pages/declaration\%20of\%20establishment\%20of\%20state\%20 of\%20israel.aspx, 7.06.2015.

20 L. Trepp, Żydzi. Naród, historia, religia, trans. S. Lisiecka, Warszawa 2009, p. 199.

21 See: Sobór Watykański II (1962-1965), Konstytucje, dekrety, deklaracje. Tekst polski, Poznań 1968. 
portance of the document in the religious sense, there was no acceleration and revive relations on the basis of politics.

However, the election of a new Pope in 1978 could herald new opening. From today's perspective the pontificate of John Paul II was productive both in the context of the dialogue of Christianity and Judaism, as well as politically. It is worth noting, nonetheless, that the relations with Israel were not settled with the start of the pontificate of the Polish Pope. The political dispute further focused on problems, generally speaking, around Jerusalem and the holy places.

The historic event took place in 1986 when John Paul II was the first in the history of the Bishop of Rome crossed the threshold of the synagogue in the Eternal City. In his speech, he called the Jews the „old and beloved” brothers of Christians. The Pope also stated that this epoch-making visit was not the culmination of overcome differences and views, as Christians and Jews were only at the beginning of the road in mutual contacts. Moreover, he said, „So I can open up my heart to you and generously prove my feelings of kindness for the entire Jewish community of Rome, and all the Jews throughout the world"22.

Vatican diplomacy was still continuing to try to minimize the obstacles, both theological and political, to prevent the conclusion of full diplomatic relations. For example, in December 1987 Pope John Paul II received Israel's ambassador in Italy ${ }^{23}$ Mordechai Drory. In the statement issued by the Embassy of the State of Israel (Holy See did not provide any details of the meeting) they informed that they had talked among others about the history of relations between Jews and the Roman Catholic Church, the fundamental importance of the State of Israel for the Jewish population, the lack of mutual diplomatic relations ${ }^{24}$. In this last respect, the Holy See recognized the status of Jerusalem, after the annexation of the Arab sector of the city by Israel, demanding to ensure his international status that would allow the coexistence of Christians, Muslims and Jews in this important place for the Church as the obstacles for a full understanding $^{25}$. In the spirit of these and other expectations, and the atmosphere of the dispute, they held diplomatic talks that led to a new opening in political relations between the Holy See and Israel at the beginning of the nineties of the twentieth century.

22 Cited from: Katolicka Agencja Informacyjna, Epokowa wizyta Jana Pawła II w rzymskiej synagodze, http://ekai.pl/wydarzenia/ostatnia_chwila/x24973/epokowa-wizyta-jana-pawla-ii-wrzymskiej-synagodze/, 8.06.2015.

23 E.J. Pałyga, Dyplomacja papieska 1914-1989 (specyfika własnej podmiotowości i form stosunków między państwami, Warszawa 1993, p. 191.

24 Ibidem.

25 Ibidem. 


\section{Fundamental Agreement - establishment of diplomatic relations}

The turbulent political situation of Israel in the Middle East at the turn of the last two decades of the last century and particularly close to the Holy See the status of Jerusalem contributed to the establishment of diplomatic relations between Santa Sede and Israel. Intense and difficult negotiations initiated by establishment of the Permanent Bilateral Working Commission on 29 July 1992, to explore and define the subject of common interests and the normalization of mutual diplomatic relations, led to the signing the Basic Agreement between the Holy See and the State of Israel on the penultimate day of 1993. According to popular opinion, it should be emphasized that the signed agreement was not a document of interreligious dialogue, but diplomatic, forming part of the efforts of the Holy See to normalize political relations with the countries of the world "in order to respect human rights, and most religious liberty of each of their residents feeling the responsibility especially for those who belong to the Catholic Church"26.

The Basic Agreement was signed in the Israeli Ministry of Foreign Affairs in Jerusalem by the Vatican's Undersecretary of the Relations with States (deputy foreign minister) Father Claudio Maria Celli and Israeli Deputy Foreign Minister Yossi Beilin. In the preamble of the document, they highlighted the specific nature and universal significance of the Holy Land, the uniqueness of the relationship between the Catholic Church and the Jews, the historical process of reconciliation and the importance of mutual understanding and friendship between Catholics and Jews. Moreover, the parties acknowledged that it would provide a solid and lasting foundation for the further development of current and future relations ${ }^{27}$.

The Agreement ... consisted of 15 articles. In article 1, special attention was paid to the idea of human rights. The State of Israel recalling its Declaration of Independence confirmed the willingness to further support and action for human rights to freedom of religion and conscience in the perspective of the Universal Declaration of Human Rights and other international regulations, of which it was party. A similar obligation incurred the Holy See at the same time invoking the conciliar document Dignitatis humanea $^{28}$. The Church also expressed its openness and respect for other religions and their followers in the spirit of the declaration Nostra aetate ${ }^{29}$.

The second article of the Agreement ... focused on the commitment of the signatories of the document for cooperation in combating all forms of anti-Semitism, racism,

26 A. Kowalski, Na fali soborowego przełomu,

http://pl.radiovaticana.va/storico/2012/09/04/na_fali_soborowego_przełomu_75_jan_paweł_ ii_1994_stosunki_z_izraelem/pol-618353, 10.06.2015.

27 See: Porozumienie... (preamble).

28 Sobór Watykański II (1962-1965)...

29 Art. 1 of the Agreement... 
religious intolerance and the promotion of mutual understanding among nations, tolerance and respect for the dignity of human life. It is worth noting that Article 2 was also a record, in which the Holy See condemned the hatred and persecution of the Jews, desecration of synagogues and cemeteries, and insult to the memory of the victims of the Holocaust.

In subsequent articles, the parties undertook, inter alia, dialogue and mutual respect for their own autonomy in the exercise of their religious, moral, educational, charitable, institutional or safety functions ${ }^{30}$. Moreover, the State of Israel confirmed the observance of the status quo of the Christian holy places and protection of Catholic churches, monasteries and cemeteries, as well as guarantees the freedom to Catholic worship ${ }^{31}$. In the adopted document, the parties acknowledged mutual interest in the promotion of Christian pilgrimages to the Holy Land. It has an integrative dimension because it contributes for a better understanding of people and religions in Israel ${ }^{32}$. The Holy See and the State of Israel also recognized the right of the Catholic Church to create and maintain schools and conduct education at all levels ${ }^{33}$. Not without significance for the signatories of the Agreement... was cultural exchange involving the cooperation of Catholic institutions with educational, cultural and research institutions in Israel $^{34}$. On the other hand, article 8 of the document acknowledged the Catholic Church the right to freedom of expression by creating their own media, while respecting the law of Israel in the media ${ }^{35}$, while another article confirmed the right of the Church to charitable activities, health care and social assistance ${ }^{36}$. The signed document also regulated the right to the property of the Church, but without prejudice to the interest of the other party in this regard ${ }^{37}$.

Another part was about the commitment of the Holy See and Israel to promote the peaceful resolution of conflicts between states and nations, with the exception of the use of violence as a means of resolving these disputes. It was here, among others, the moral and spiritual support ${ }^{38}$.

Articles 12 to 15 were of a technical nature. At first, the parties agreed to continue negotiations in accordance with the agenda adopted in Jerusalem and confirmed by the Vatican in July $1992^{39}$. Art. 13 defined terms used in the text of the agreement,

\footnotetext{
30 See: art. 3 of the Agreement...

31 See: art. 4 of the Agreement...

2 See: art. 5 of the Agreement...

3 See: art. 6 of the Agreement...

See: art. 7 of the Agreement...

See: art. 8 of the Agreement...

See: art. 9 of the Agreement...

7 See: art. 10 of the Agreement...

8 See: art. 11 of the Agreement...

39 See: art. 12 of the Agreement...
} 
i.e. the Catholic Church, the community of the Catholic Church, the State of Israel ${ }^{40}$. Art. 14 was especially important in my opinion. It was a rise to the establishment of full diplomatic relations. The agreement committed the Holy See and the State of Israel to exchange representatives, whose rank and privileges wee specified in the additional protocol. It was considered that after the entry into force of the Agreement, the signatories would establish diplomatic relations at the level of Apostolic Nunciature on the part of the Holy See and the Embassy of the State of Israel ${ }^{41}$. The Agreement was done in duplicate, in the English and Hebrew languages. However, both parties concluded that in the case of divergence, the English text should prevail. Moreover, it was assumed that the agreement should enter into force on the date of ratification by the last party to the agreement ${ }^{42}$.

Pursuant to the Agreement ... - even before the ratification (as indeed the protocol to art. 14 assumed) John Paul II appointed a "special representative" in the rank of Nuncio, though so far without the nunciature on 18 January 1994. It was Archbishop (later Cardinal) Andrea Cordero Lanza di Montezemolo, who had served as apostolic delegate in Jerusalem and Palestine for four years. The day before, the Council of Ministers of Israel made a similar movement by appointing a "special representative" holding the rank of Ambassador (until ratification without an embassy) Shmuel Hadassah. Israel ratified the Agreement... It began to apply on 10 March 1994, and both parties established full diplomatic relations on 15 June. The above-mentioned Archbishop became the head of the nunciature in Tel Aviv-Jaffa, while maintaining the apostolic delegation in Jerusalem and Palestine. The hierarch presented his credentials to the President of Israel Ezer Weizmann on 16 August 1994. The former "special representative" to the Holy See that State also received the nomination for the Israeli ambassador. Shmuel Hadas presented his credentials on 29 September $1994^{43}$. In a special message on that occasion, John Paul II wrote among others: „(...) the establishment of diplomatic relations is not an end in itself, but a starting point for specific cooperation, taking into account the nature of the Holy See and the State of Israel. Various issues concerning both parties are still considered by the two sub-committees, set up in accordance with the provisions of the "Agreement« of 30 December last year designed to enable the development of our mutual cooperation based on a solid foundation" ${ }^{\prime 4}$.

40 See: art. 13 of the Agreement...

41 See: art. 14 of the Agreement...

42 See: art. 15 of the Agreement...

43 A. Kowalski, Na fali soborowego przełomu, http://pl.radiovaticana.va/storico/2012/09/04/ na_fali_soborowego_przełomu_75_jan_pawel_ii_1994_stosunki_z_izraelem/pol-61835 14.06.2015.

44 Cited from: ibidem. 
In this context it should be noted, however, that the establishment of diplomatic relations created a new political reality, but did not eliminate the old problems, which in the following years were, and in many respects they have been up till now, the main axis of the dispute, or even a crisis in relations between the Holy See and Israel.

\section{Diplomatic relations since the Basic Agreement - Selected Problems}

Despite the exchange of ambassadors and regular meetings of the delegation of the Holy See and Israel since the signing of the Basic Agreement, it has been difficult to lead to a comprehensive agreement governing a number of issues. The establishment of diplomatic relations can be considered a "milestone" in bilateral relations, although this event and the adoption of the aforementioned document does not resolve, in my opinion, the quintessential problem, i.e. the legal status of the Catholic Church in the Holy Land, its properties and controversial economic and fiscal issues. by the Vatican's disagreement on the recognition of Jerusalem as the capital of Israel, or reluctance to the idea of the so-called a two-state solution to the dispute in the Middle East also made the situation even more difficult ${ }^{45}$. This is of course only part of the problems between the Holy See and Israel, which could be observed in the last twenty years.

Analyzing the above problems there is some doubt, especially with regard to legal issues, and financial status of the Church in the Holy Land, namely, why was the Agreement concluded... without prior resolution of all contentious issues? One of the negotiators of the agreement with Israel Fr. David Maria A. Jaeger pointed out that the Holy See showed the "magnanimity", "good faith", "unconditional trust in the other side" and "bold" and "generous" attitude of John Paul $\mathrm{II}^{46}$.

The next comprehensive regulation of disputable points was included in the supplementary agreement of 10 November $1997^{47}$ regarding legal issues. This document clearly alluded to the 1993 agreement and determined the legal status of the Catholic Church in Israel, as well as the status of the church hierarchy in the legislation of the country. The problem, however, is that the terms of the agreements were not respected, which in recent years has repeatedly contributed to the crisis in relations between the Holy See and Israel. In 2007, Archbishop Pietro Samland triggered a diplomatic

45 Watykan i Izrael: od nieufności do pojednania, https://www.tygodnikpowszechny.pl/watykan-i-izrael-od-nieufnosci-do-pojednania-22982, 14.06.2015.

46 O. Jeager o rokowaniach watykańsko-izraelskich, http://papiez.wiara.pl/doc/374099.O-Jeager-o-rokowaniach-watykanskoizraelskich, 18.06.2015.

47 Legal Personality Agreement: State of Israel - Holy See, 10 November 1997. http://www. $\mathrm{mfa}$. gov.il/mfa/mfa-archive/1996-1997/pages/legal\%20personality\%20agreement-\%20state\%20 of\%20israel-holy.aspx, 18.06.2015. 
crisis accusing Israel of lack of good will. He said that relations between the Holy See and Israel had been better before 1993. In an interview with the internet portal of the Franciscan Custody of the Holy Land, the hierarch argued that the establishment of diplomatic relations with Israel was on the part of Santa Sede „an expression of confidence". According to the archbishop, the trust was disappointed, because Israel had not fulfilled its commitments. Interestingly, the then spokesman for the Vatican retorted the hierarchy's words, while expressing hope for a rapid conclusion of negotiations on the implementation of agreements on church property, legal and tax issues ${ }^{48}$.

In this context, the statement of Rabbi David Rosen was significant. In the newspaper „Haaretz” in 2010, he found that the conduct of Israel in relation to the Vatican over the past 15 years had been „outrageous”. Rabin recalled that an agreement of 1993 was possible, among others, due to the fact that the Holy See received an assurance from the Israeli side that the legal status of church institutions in the Holy Land would be recognized, and church property in Israel would be exempt from tax. „After 15 years, the state still has not ratified the agreement on the legal status of the Church. (...) Any other country would already threaten with the withdrawal of its ambassador because of Israel's lack of respect for the terms of the agreement", said the chairman of The International Jewish Committee on Interreligious Consultations ${ }^{49}$.

In the last two decades, both parties, as well as the media have repeatedly reported on the progress of negotiations and the conclusion of appropriate agreements regulating legal and economical issues. For instance, in 2009 media published a communiqué from the Israeli Embassy to the Holy See on the progress in the discussions on, among others, the issue of taxes and the return of church property. Operating in Poland, the Catholic Information Agency reminded on this occasion that ongoing for many years the Israeli-Vatican negotiations were to lead to the signing of a general treaty regarding the unsettled tax and ownership issues. „The Church wants the acknowledgement of tax reductions for their non-profit institutions that serve the local population. They were respected both by the Ottoman Turkish governments, and at a time when the Holy Land was under the British Mandate. The State of Israel also confirmed them at the time of its creation in 1948. (...) The Basic Agreement signed in 1993 between Israel and the Holy See states about the need for regulation of economic issues. The same was repeated in the supplementary agreement 1997 regarding the legal issues. However, so far Israel has not ratified either the Basic Agreement or the agreement on legal issues. The Holy See has repeatedly asserted that it would not agree to an agreement detrimental

48 JEN, Kryzys $w$ stosunkach watykańsko-izraelskich, http://www.rp.pl/artykul/69999.html?print=tak, 18.06.2015.

49 Katolicka Agencja Informacyjna, „Izrael zstosunku do Watykanu zachowywał się skandalicznie”, http://ekai.pl/wydarzenia/ekumenizm/x24994/izrael-w-stosunku-do-watykanu-zachowywalsie-skandalicznie/, 22.06.2015. 
to the future of Christians in the Holy Land"50, was emphasized in the message of the Catholic Information Agency.

In 2013 there were also reports about the Israeli-Vatican agreement being close to finish. In addition to economic and tax issues the right of the Franciscans to the Upper Room was also to be settled ${ }^{51}$. „In the perspective of the meeting of both sides (...) it is believed that the signing of the agreement is very close. To determine, believes the Israeli side, only "details" are left" 52 , reported one of the messages. Media reports indicated that in relation to economic matters that influenced (influence) on the delay in the adoption of the agreement, they accepted the principle of double taxation. This means that places of worship are exempt from fees, and church institutions engaged in business activities, for example, Pilgrim's Houses will be taxed ${ }^{53}$. The bone of contention in the relationship is the visa policy of Israel. In 2002, Israeli Ministry of Foreign Affairs introduced restrictions for stays longer than three months. The new policy in this regard was not discriminatory; it was dictated by safety considerations after the events of September 2001 in the United States and the start of the second intifada. However, it touched a large group of Catholic clergy, which the Holy See has considered a breach of contract on mutual relations.

An opportunity to solve the above problems was year 2014, i.e. the twentieth anniversary of the signing of the Agreement .... The settlement did not happen. Vatican Secretary of State Cardinal Pietro Parolin expressed only hope for a "rapid finalization of the talks on the status of the institution of the Catholic Church in the State of Israel, jurisdiction over the holy places, the issue of visas and the use of the Cenacle" 54 .

Analyzing the diplomatic relations between the Holy See and the State of Israel after the signing of the Agreement ..., in addition to legal and economic problems, we should also pay attention to the activity of successive Popes in terms of shaping relations with Israel on the political and interreligious dialogue. Especially that the period after 1993 was the pontificates of three Bishops of Rome.

Looking at one of the longest pontificates in the history of the Catholic Church, you can venture to say that the dialogue with the Jews was one of the policy priorities

50 Katolicka Agencja Informacyjna, Watykan - Izrael: postępy w negocjacjach, http://ekai.pl/ wydarzenia/watykan/x18253/watykan-izrael-postepy-w-negocjacjach/, 22.06.2015.

51 The negotiations included the problem of the Upper Room. The annex to the agreement was to regulate legal take over administration of the Shrine of the Last Supper by the fathers of the Franciscan Custody of the Holy Land.

52 Tygodnik Katolicki „Niedziela”, Porozumienie izraelsko-watykańskie bliskie finiszu, http://www.niedziela.pl/artykul/5083/Porozumienie-izraelsko-watykanskie, 23.06.2015.

53 Ibidem.

54 Watykan: obchody 20. rocznicy podpisania umowy między Izraelem a Stolica Apostolska, http://www.idziemy.pl/polityka/watykan-obchody-20-rocznicy-podpisania-umowy-miedzy-izraelem-a-stolica-apostolska, 27.06.2015. 
of Pope John Paul II. On the one hand symbolic epoch-making gestures, on the other hand numerous texts and statements recognizing the right of Jews to the Holy Land ${ }^{55}$. "Jews, who during two thousand years scattered throughout the world, decided to return to ancestral lands and have the right to do so"56, said the Pope in 1994. The longawaited and widely commented pilgrimage to Jordan and Israel was one of the most important events of his pontificate ${ }^{57}$. Millennium visit to the Holy Land proceeded not only under the sign of the presence of the places associated with Christianity. The Pope prayed at the Western Wall, and paid homage to the victims of the Shoah at Yad Vashem. He met with religious leaders of Christians, Jews and Muslims. As rightly observes Hayssam Obeidat „in Israel, the Pope also did not hesitate to recall the rights of the Palestinian people, (...), saying among other things that »for decades the nation has suffered severely and suffered injustice «"58.

Benedict XVI began his pontificate in a difficult moment for the Church. He had to face many internal problems of the institution. He felt also a responsibility for the legacy of his predecessor, but he did not want to imitate John Paul II. After being elected the Pope, Joseph Ratzinger said: „After the great Pope John Paul, the cardinals have elected me, plain and humble laborer of the Lord's vineyard"59. Benedict departed from the model of a charismatic leader of the Church, during his pontificate, which already in 2005, many perceived as transitional, to deal with the tedious, primarily theological repairing of the church ${ }^{60}$.

In the early days in office, Benedict XVI spoke several times on the ChristianJewish relationship, the statements appeared as topics concerning the relations of the Holy See with the State of Israel. However, you can see here a clear distinction between religious and political issues, which for many Jewish communities should be kept in close symbiosis. In this context, it is worth quoting part of the article by Fr. John T. Pawlikowski, published on the monthly magazine "Znak”: „At an international conference held in 2005 at the Pontifical Gregorian University in Rome, Dr. Ruth Langer of Boston College, a prominent figure in Jewish-Christian relations, argued that the attachment of Jews to the land of Israel must become part of interfaith dialogue. Now maintained by the Vatican the distinction between religious relations with the Jewish

55 See more: W. Chrostowski, Żydzi i judaizm w nauczaniu Jana Pawła II (1978-2005), Warszawa 2005.

56 B. Fastyn, Jan Paweł II wobec konfliktu izraelsko-palestyńskiego, Warszawa 2002, p. 86.

57 G. Weigel, Kres i początek. Papież Jan Paweł II - zwycięstwo wolności, ostatnie lata, dziedzictwo, Kraków 2012, passim.

58 Cited from: H. Obeidat, Jan Pawet II wobec konfliktu arabsko-izraelskiego i wojny w Iraku, „Krakowskie Studia Międzynarodowe” nr 1/2007, p. 51.

59 G. Polak, Benedykt XVI. Historia wyboru, Sopot 2005.

60 T. Bielecki, Jak zapamiętamy pontyfikat Benedykta XVI, http://wyborcza. pl/1,76842,13481930,Jak_zapamietamy_pontyfikat_Benedykta_XVI.html, 29.06.2015. 
community (...) and political discussions led by the Vatican secretariat of state simply can not be reconciled with the position of the Jews in this matter. Langer argued that contemporary Jewish religious identity involves a deep connection with the land of Israel. (...) The Jews are increasingly viewing separate treatment by the Vatican of religious and political relations with the Jewish community in the world as a thing not to be accepted (...)" ${ }^{\prime \prime}$. In my opinion, the Pope wanted to maintain good relations with Israel. On the 60th anniversary of the founding of this country, Benedict XVI conveyed wishes to the Israeli authorities, expressing hope for a peaceful solution to the conflict with Palestinians. During the meeting with the Israeli ambassador to the Vatican, the Pope said among others: „The Holy See thanks God for the fact that the aspirations of the Jewish people to have a home on the land of their fathers have been realized"62. It should be noted, however, that Benedict XVI, like his predecessor, was disappointed by the lack of settlement resulting from the agreement of 1993.

Diplomatic relations between the Holy See and the State of Israel during the pontificate of Benedict XVI were not free of glitches and crises. I would like to draw attention to two issues. I already wrote above about the first issue related to the beatification of Pope Pius XII. Let me remind you that in 2007 Pope Pius stopped the process of recognition of the blessed. It is believed the decision to be influenced by the concern of Benedict XVI about the negative consequences of raising Pius to the altars for Vatican-Israeli relations and dialogue with Judaism, although Israel officially claimed that the beatification was an internal matter of the Church.

A crisis in the relationship occurred in 2009. In German media there were even suggestions (quickly denied) that Israel was considering breaking off diplomatic relations with the Holy See. This was to be the aftermath of a controversial decision of Benedict XVI to rehabilitate and remove the excommunication of Bishop Richard Williamson, a Lefebvrist, who denied the Holocaust. The priest is considered a denier and antiSemite. He claimed, among others, that in the concentration camps there were not any gas chambers. Interestingly, in January 2009, he released a letter to Pope Benedict XVI, in which he apologized for the media storm, which his speech denying the Holocaust caused, although he did not mention, however, what was the content of this statement: „In the midst of the huge media storm, caused by my imprudent remarks uttered for Swedish television, I beg for admission with all due respect of my deep regret because of causing to your Eminence, and the Holy Father so much unnecessary distress

61 J.T. Pawlikowski, Krok wstecz czy potwierdzenie? Benedykt XVI o Żydach i judaizmie, „Znak” No 9, 2009.

62 Benedykt XVI dziękuje Bogu za Izrael, http://www.jewish.org.pl/index.php/pl/wiadomopci-mainmenu-57/1426-benedykt-xvi-dzije-bogu-za-izrael.html, 6.07.2015. 
and problems"63. Without going much into criticism expressed in this context by the Jewish community, it is enough to mention the statement of spokesperson of the Israeli Foreign Ministry. Commenting on the statement of Israeli Minister of Religious Affairs Yitzhak Cohen that he recommended the suspension of relations with the „organization, whose members are Auschwitz liars and anti-Semites”, Igal Palmor declared that Israel diplomatic relations were the prerogative of the Ministry of Foreign Affairs, not the Ministry of Religions Affairs. Moreover, he added that the Israeli diplomacy was not going to speak about the removal of excommunication of the bishops Lefebvre, because the problem did not apply to relations between the states ${ }^{64}$.

A pilgrimage of Benedict XVI to Jordan, Israel and the Palestinian Authority took place a few months later in May 2009. In my view, the visit can be regarded as the culmination of his pontificate in the field of the topic which is our main point of interest in this article. Undoubtedly, the Pope came to the Holy Land in a difficult moment, if only because of a problem with Bishop Williamson. For commentators and observers of the activity of Benedict XVI the visit was the biggest challenge of his pontificate and the next stage of the dialogue between the Holy See and the State of Israel, which began in the early nineties of the twentieth century. The pilgrimage was also regarded historical, but political commentaries were balanced. In its course, the Pope acknowledged the right of the State of Israel to exist, peace and security at the international level. He also stressed that the Holy See supports the right of the Palestinian people to a sovereign country within the limits recognized by the international community.

Benedict XVI's resignation from office in February 2013 was for many a shock. The Church faced a completely new, previously unknown reality. Elected a few weeks later, the new Pope has performed friendly gestures toward the Jews since the beginning of his pontificate. Shortly after the election, Francis announced his intention to visit Israel. The pilgrimage took place in May 2014. In its course, he appealed to the parties to the conflict in the Holy Land for the renunciation of action, which contradicted the declared desire for reconciliation, and would see Jerusalem as a city of peace.

63 Katolicka Agencja Informacyjna, Bp Williamson przeprasza Benedykta XVI: „Weźcie mnie i rzućcie w morze",

http://ekai.pl/wydarzenia/swiat/x17900/bp-williamson-przeprasza-benedykta-xvi-wezcie-mniei-rzuccie-w-morze/, 6.07.2015.

64 From: Izrael: Zerwanie stosunków dyplomatycznych $z$ Watykanem wykluczone, http://www.rmf24.pl/fakty/swiat/news-izrael-zerwanie-stosunkow-dyplomatycznych-z-watykanem-wykluc,nId,197196, 14.07.2015. 


\section{Summary}

Negotiations of the Holy See with Israel governing the mentioned above problems arising from the agreement concluded in the nineties of the last century, have been continuing up till now ${ }^{65}$. However, it is hard, looking at past experience of those complex relationships, to formulate clear scenarios for the future. Especially that in June 2015 representatives of the Holy See and the Palestinian State signed the historic General Agreement, which regulates the basic aspects of life and functioning of the Catholic Church in Palestine. The agreement confirmed the support for a negotiated peaceful solution to the Israeli-Palestinian conflict. The Holy See recognized Palestine as a state ${ }^{66}$.

In this context, it remains an open question as to how the agreement will result in the relations of the Holy See and Israel. The first comments are not optimistic. Namely, the Israeli side expressed „regret” because of this decision. They also stressed that this step would "harm the pursuit of peace agreement" 67 and is a „one-sided" and ,ignoring the historical rights of the Jewish people"68. In my opinion, it may also lead to a negative impact on Vatican-Israel negotiations on legal and economic matters and constitute inducement to cool diplomatic relations between the Holy See and the State of Israel. Commenting on conducting the June agreement, Abraham H. Miller, professor emeritus of political science at the University of Cincinnati, and a researcher at Salomon Center for American Jewish Thought, stated that the official recognition of a Palestinian state may be a manifestation of the fact that the Holy See applies to the teachings of Jesus to render unto Caesar the things that are Caesar's, and unto God the things that are God's. „Although the recognition of a Palestinian state will be a largely ceremonial role, it is a generous remuneration for Mahmoud Abbas for sabotaging peace talks with Israel and for putting the next generation of Palestinians terrorists as an example, so that they do not hesitate to blow up themselves among a crowd of innocent people. This act does not contribute to the creation of a Palestinian state, but it is a strong signal showing how Israel is isolated diplomatically"69, said Miller. Representatives of the

65 As of July 2015.

66 See more: Katolicka Agencja Informacyjna, Stolica Apostolska podpisała Układ Ogólny z Palestyna, http://ekai.pl/wydarzenia/swiat/x90307/stolica-apostolska-podpisala-uklad-ogolnyz-palestyna/, 16.07.2015.

67 See: Izrael „ubolewa” z powodu porozumienia Watykan-Palestyna, http://www.tvp.info/20627821/izrael-ubolewa-z-powodu-porozumienia-watykanpalestyna, 16.07.2015.

68 See: Umowa Watykanu z Palestyna ubodła Izrael, http://gosc.pl/doc/2564084.Umowa-Watykanu-z-Palestyna-ubodla-Izrael, 16.07.2015.

69 A.H. Miller, Watykan - Palestyna: akt desperackiej dyplomacji,

http://www.euroislam.pl/index.php/2015/05/watykan-palestyna-akt-desperackiej-dyplomacji/, 16.07.2015. 
Holy See maintain, however, that the agreement is not aimed at Israel, as it is an example of dialogue, openness and cooperation in the name of peace and justice.

Unambiguous assessment of the undertaken research problem and expressed in the title of this article is difficult because of protracted negotiations and disputes, discords, sometimes unnecessary, and not intended as the idea of full reconciliation statements or gestures. However, I assess positively the twenty years of diplomatic relations between the Holy See and the State of Israel, celebrated in 2014. In my opinion, and this is one of the main conclusions made in the context of the above analysis, at these relations we should look in the broader context, not limited to the problems of a political nature. Extremely important here is the theological realm, the context of dialogue between Christianity with Judaism, which in this case influences, like anywhere else, on the politics, and thus the diplomatic relations. Moreover, we should also take into account the historical context. Suffice it to mention that since the beginning of the activities of the Holy See and the various Popes to Israel they were characterized by caution and restraint. Establishment of diplomatic relations in the early nineties of the twentieth century and the recognition of the State of Israel was the result of a combination of various political and religious issues, including concerns of the Holy See against the growing tension in the Middle East, which actually threatened the Christian community, the Church's concern about the holy places and the status of Jerusalem, the issues of ecumenism and interreligious dialogue in the spirit of Vaticanum Secundum. Also, we must not forget that the "milestone" in relations with Israel coincided with the pontificate of John Paul II, who specifically referred to the Jewish communities. In this context, it is worth recalling that the Pope was close to the political aspirations of the Palestinians.

In the face of the events of 2015, the future of the difficult diplomatic relations with the Holy See, the State of Israel is intriguing and important, which certainly deserve a scientific reflection and evaluation.

\section{Bibliography}

Benedykt XVI dziękuje Bogu za Izrael, http://www.jewish.org.pl/index.php/pl/wiadomopci-mainmenu-57/1426-benedykt-xvi-dzije-bogu-za-izrael.html [access: 6.07.2015].

Besier G., Stolica Apostolska i Niemcy Hitlera, Warszawa 2010.

Bielecki T., Jak zapamiętamy pontyfikat Benedykta XVI, http://wyborcza.pl/1,76842,13481930,Jak_ zapamietamy_pontyfikat_Benedykta_XVI.html, [access: 29.06.2015].

Chrostowski W., Żydzi i judaizm w nauczaniu Jana Pawła II (1978-2005), Warszawa 2005.

Code of Canon Law of 25 January 1983.

Fastyn B., Jan Paweł II wobec konfliktu izraelsko-palestyńskiego, Warszawa 2002.

Fundamental Agreement between the Holy See and the State of Israel, 30 December 1993. Israel Ministry of Foreign Affairs, 
http://www.mfa.gov.il/mfa/foreignpolicy/mfadocuments/yearbook9/pages/151\%20fundamental\%20agreement\%20between\%20the\%20holy\%20see\%20and.aspx, [access: 24.05.2015].

Ignatowski G., Stolica Apostolska wobec Państwa Izrael w okresie wojny sześciodniowej, „Śląskie Studia Historyczno-Teologiczne" vol.42, book 2, 2009.

Izrael „ubolewa" z powodu porozumienia Watykan-Palestyna, http://www.tvp.info/20627821/izraelubolewa-z-powodu-porozumienia-watykanpalestyna [access: 16.07.2015].

Izrael: Zerwanie stosunków dyplomatycznych $z$ Watykanem wykluczone, http://www.rmf24.pl/fakty/swiat/news-izrael-zerwanie-stosunkow-dyplomatycznych-z-watykanemwyklucnId,197196 [access: 14.07.2015].

JEN, Kryzys w stosunkach watykańsko-izraelskich, http://www.rp.pl/artykul/69999.html?print=tak [access: 18.06.2015].

Katolicka Agencja Informacyjna, „Izrael z stosunku do Watykanu zachowywat się skandalicznie", http://ekai.pl/wydarzenia/ekumenizm/x24994/izrael-w-stosunku-do-watykanuzachowywalsie-skandalicznie/ [access: 22.06.2015].

Katolicka Agencja Informacyjna, Bp Williamson przeprasza Benedykta XVI: „Weźcie mnie i rzućcie w morze", http://ekai.pl/wydarzenia/swiat/x17900/bp-williamson-przeprasza-benedykta-xviwezcie-mnie-irzuccie- w-morze/ [access: 6.07.2015].

Katolicka Agencja Informacyjna, Epokowa wizyta Jana Pawła II w rzymskiej synagodze, http:// ekai.pl/wydarzenia/ostatnia_chwila/x24973/epokowa-wizyta-jana-pawla-ii-w-rzymskiejsynagodze/ [access: 8.06.2015].

Katolicka Agencja Informacyjna, Stolica Apostolska podpisała Układ Ogólny z Palestyna, http:// ekai.pl/wydarzenia/swiat/x90307/stolica-apostolska-podpisala-uklad-ogolny-z-palestyna/ [access: 14.07.2015].

Katolicka Agencja Informacyjna, Watykan - Izrael:postępy w negocjacjach, http://ekai.pl/wydarzenia/watykan/x18253/watykan-izrael-postepy-w-negocjacjach/ [access: 22.06.2015].

Klarecki R., Polityka Stolicy Apostolskiej wobec Chin. Przeszłość, teraźniejszosśc i przyszłość, Toruń 2014.

Kowalski A., Na fali soborowego przełomu, http://pl.radiovaticana.va/storico/2012/09/04/na_ fali_soborowego_przełomu_75_jan_paweł_ii_1994_stosunki_z_izraelem/pl-618353 [access: 10.06.2015].

Krukowski J., Konkordaty z państwami Europy Środkowej i Wschodniej zawarte na przełomie XX i XXI wieku, „Teka Komisji Prawniczej O.L. PAN” No3, 2010.

Legal Personality Agreement: State of Israel - Holy See, 10 November 1997. http://www.mfa.gov. $\mathrm{il} / \mathrm{mfa} / \mathrm{mfa}$-archive/1996-1997/pages/legal\%20personality\%20agreement-\%20state\%20of\%20 israel-holy.aspx [access: 18.06.2015].

Miller A. H., Watykan - Palestyna: akt desperackiej dyplomacji, http://www.euroislam.pl/index. php/2015/05/watykan-palestyna-akt-desperackiej-dyplomacji/ [access: 16.07.2015]

Montefiore S.S., Jerusalem. Biography, New York, 2011.

O. Jeager o rokowaniach watykańsko-izraelskich, http://papiez.wiara.pl/doc/374099.O-Jeager-orokowaniach-watykanskoizraelskich [access: 18.06.2015].

Obeidat H., Jan Paweł II wobec konfliktu arabsko-izraelskiego i wojny w Iraku, „Krakowskie Studia Międzynarodowe" nr 1 z 2007.

Olejarz T., Podmiotowość Stolicy Apostolskiej w stosunkach międzynarodowych, „Annales Universitatis Mariae Curie-Skłodowska" (sectio K) No 1, 2009.

Pałyga E. J., Dyplomacja papieska 1914-1989 (specyfika własnej podmiotowości i form stosunków między państwami, Warszawa 1993.

Pawlikowski J.T., Krok wstecz czy potwierdzenie? Benedykt XVI o Żydach i judaizmie, „Znak” No 9, 2009.

Polak G., Benedykt XVI. Historia wyboru, Tower Press, Sopot 2005.

Sobór Watykański II (1962-1965), Konstytucje, dekrety, deklaracje. Tekst polski, Poznań 1968.

Tauran J.L., Stolica Apostolska i Ziemia Święta: sprawiedliwość i miłosierdzie, http://www.opoka. org.pl/biblioteka/T/TH/THW/sprawiedliwosc_milosierdzie.html, [access: 6.06.2015]. 
The Declaration Of The Establishment Of The State Of Israel, 14 May 1948, http://www.mfa.gov.il/ $\mathrm{mfa} /$ foreignpolicy/peace/guide/pages/declaration $\% 20 \mathrm{of} \% 20$ establishment $\% 20 \mathrm{of} \% 20$ state $\% 20$ of\%20israel.aspx [access: 7.06.2015].

Tornielli A., Pius XII. Papież, który ratowat Żydów, Kraków 2015.

Trepp L., Żydzi. Naród, historia, religia, przeł. S. Lisiecka, Warszawa 2009.

Tygodnik Katolicki „Niedziela”, Porozumienie izraelsko-watykańskie bliskie finiszu, http://www. niedziela.pl/artykul/5083/Porozumienie-izraelsko-watykanskie [access: 23.06.2015].

Umowa Watykanu z Palestyna ubodła Izrael, http://gosc.pl/doc/2564084.Umowa-Watykanu-zPalestyna-ubodla-Izrael [access: 16.07.2015].

Watykan i Izrael: od nieufności do pojednania, https://www.tygodnikpowszechny.pl/watykan-i-izraelod-nieufnosci-do-pojednania-22982 [access: 14.06.2015].

Watykan: obchody 20. Rocznicy podpisania umowy między Izraelem a Stolica Apostolska, http:// www.idziemy.pl/polityka/watykan-obchody-20-rocznicy-podpisania-umowy-miedzy-izraelem-a-stolica-apostolska [access: 27.06.2015].

Weigel G., Kres i początek. Papież Jan Paweł II - zwycięstwo wolności, ostatnie lata, dziedzictwo, Kraków 2012.

\section{Twenty years of diplomatic relations between Vatican City state and Israel}

ABSTRACT

Basic Agreement concluded between the Vatican City State and Israel in 1993 was an important step for the establishment of diplomatic relations. The conclusion of this Agreement is not a question of interreligious and diplomatic, which was associated with the efforts of the Vatican normalization of political relations with various countries. The author has analyzed the document and assess the relations in the perspective of twenty years. He also pointed to the fundamental problems in bilateral relations, and presented an assessment of contemporary relationships. The challenge for the future relations both states will be a consequence of the recognition in 2015 by the Vatican City State independence of Palestine.

\section{Dwadzieścia lat stosunków dyplomatycznych pomiędzy Państwem Watykańskim a Izraelem}

STRESZCZENIE

Porozumienie podstawowe zawarte między Państwem Watykańskim a Izraelem w 1993 roku było ważnym krokiem dla nawiązania stosunków dyplomatycznych. Zawarcie tego Porozumienia nie było kwestią międzyreligijną a dyplomatyczną, która związana była ze staraniami Watykanu normalizacji stosunków politycznych z różnymi państwami. Autor dokonał analizy dokumentu oraz oceny wzajemnych stosunków w perspektywie dwudziestu lat. Wskazał także na podstawowe problemy w relacjach dwustronnych oraz przedstawił ocenę współczesnych relacji. Wyzwaniem dla przyszłych relacji obu państw będzie konsekwencja uznania w 2015 roku przez Państwo Watykańskie niepodległości Palestyny. 